\title{
INTELECTUAIS ORGÂNICOS E LEGITIMAÇÃO DO ESTADO NO MOÇAMBIQUE PÓS-INDEPENDÊNCIA: O CASO DO CENTRO DE ESTUDOS AFRICANOS
}

(1975-1985)

\author{
Carlos Fernandes"
}

$\mathrm{O}$

presente artigo analisa as condições sociais da produção de conhecimento científico e legitimação do Estado em Moçambique durante o período da "transição socialista" (1975-1985), ${ }^{1}$ tendo como caso de estudo o Centro de Estudos Africanos (CEA) da Universidade Eduardo Mondlane (UEM). Dois objetivos específicos guiarão esta discussão. O primeiro é reconstituir a história intelectual do CEA, descrevendo o contexto social e político da sua gênese, os seus membros fundadores, linhas de pesquisa, metodologias e abordagens teóricas. O segundo objetivo subdivide-se em duas partes: analisar a relação entre a produção de conhecimento e o contexto político da construção do socialismo em Moçambique e das lutas de libertação nacional na região austral; e examinar a função intelectual que o CEA

Pós-doutorando no Centro de Pesquisa das Humanidades (CHR), Universidade de Western Cape, Cidade do Cabo, África do Sul. Agradeço aos pareceristas anônimos, pelas úteis sugestões e comentários críticos, e ao CHR/PSHA/UWC por proporcionar-me uma atmosfera intelectual instigante fundamental na produção deste artigo. E-mail: kulunguane@hotmail.com

1 Traçar limites cronológicos rigorosos sobre este contexto histórico pode ser problemático. Neste estudo preferimos olhar para esta fase de uma forma fluida, processual, sem contudo deixar de usar como marcos temporais: 1975, quando se dá a independência nacional; 1976, o nascimento do CEA; e 1984, com a assinatura dos Acordos de Nkomati, e que terão - como veremos neste estudo - repercussões tanto políticas e econômicas, como também na própria história intelectual do CEA. 
desempenhou na legitimação do Estado. Esta análise será conduzida a partir do conceito de intelectual orgânico, de Antonio Gramsci, reforçado ainda pelo conceito de engajamento crítico de Allen Isaacman. ${ }^{2}$ Estes dois conceitos nos ajudarão a enfatizar o caráter heterogêneo e plurivocal do CEA, a função que os seus pesquisadores tiveram ao estabelecer a ligação entre sociedade civil e sociedade política e na definição de um tipo de ciência social inovadora, que se pretendia, ao mesmo tempo, politicamente engajada, aplicada, crítica e autorreflexiva.

$\mathrm{O}$ argumento central deste artigo é que os processos da produção de conhecimento científico, numa situação histórica particular de Moçambique (1975-1985), adquiriram dinâmicas próprias que desafiaram os pressupostos epistêmicos dentro dos quais a universidade em Moçambique devia produzir conhecimento, ${ }^{3}$ e que isso explicaria não somente o caráter ambíguo do trabalho científico do CEA, na relação de proximidade/distanciamento com o poder político, mas as condições em que as ciências sociais ganharam contornos em Moçambique como modo privilegiado de produção de conhecimento sobre a sociedade. Isso tanto na introdução de um tipo de pesquisa coletiva que respondia a preocupações candentes e atuais do governo, quanto no privilégio do paradigma da economia política marxista e da ênfase nos processos de transformação social; na criação de um curso de pós-graduação que visava estudantes universitários e funcionários do Estado; e, mais importante ainda, na preservação de um tipo de ciência social que procurava refletir sobre as próprias condições da produção de conhecimento.

\section{O nascimento do Centro de Estudos Africanos (CEA)}

Moçambique testemunha, na altura da independência, em 1975, o êxodo maciço de professores universitários portugueses, como de estudantes,

2 Allen Isaacman, "Legacies of Engagement: Scholarship Informed by Political Commitment", African Studies Review, v. 46, n.1 (2003), pp. 1-41.

3 Ver, por exemplo, a tônica do reitor da Universidade Eduardo Mondlane, Fernando Ganhão, na distinção entre a teoria da "transformação social" e a teoria "burguesa" e "reacionária" da ordem social; mas, por outro lado, no interior do CEA, as diferentes abordagens teóricas e metodológicas da Oficina de História do Núcleo da África Austral, e do Curso de Desenvolvimento: Fernando Ganhão, "Problemas e prioridades na formação em Ciências Sociais", Estudos Moçambicanos, n. 4 (1984), pp. 5-17. 
criando uma situação de crise total na única instituição de ensino superior existente. Os números falam por si: nestes primeiros anos pós-independência, o grosso dos estudantes tinha-se reduzido de 2.433 para 740 , somente no período entre 1975 e 1978, enquanto o número de docentes moçambicanos reduziu-se para menos de 10 professores. ${ }^{4}$ Devido a essa falta de professores universitários, a universidade nos primeiros anos pós-independência teve que "improvisar" usando "alunos-monitores", que colaboravam na docência e investigação, sob a orientação direta de um professor.

Os únicos cursos na área de Ciências Sociais na universidade eram o de Filologia Românica e os bacharelados em História e Geografia, profundamente eurocêntricos e virados para a exaltação da cultura e valores portugueses. Agravando, ainda, o fato de que em Moçambique só estava disponível o primeiro ano. Os estudantes que quisessem continuar teriam impreterivelmente que viajar para a "metrópole". No pós-independência, os cursos de Ciências Sociais permaneceram relativamente os mesmos. A licenciatura em História seria somente introduzida em 1989, e os cursos de Sociologia, Antropologia, Ciências Políticas, apenas em 1995, no âmbito da criação da Unidade de Investigação e Formação em Ciências Sociais (UFICS).

Em janeiro de 1976, a Universidade inicia o seu primeiro ano letivo. Em maio do mesmo ano, deu-se a mudança do nome de Universidade de Lourenço Marques para Universidade Eduardo Mondlane (UEM), em homenagem ao primeiro presidente da Frente de Libertação de Moçambique (FRELIMO). Esta modificação marcava simbolicamente a tentativa do poder político efetuar uma "ruptura completa com o passado colonial" ${ }^{5}$ e impor uma nova concepção de ensino superior. Uma universidade popular a serviço da sociedade moçambicana "rumo ao socialismo". Aos quadros da nova universidade era requerido que se apetrechassem com a "teoria (marxista) da mudança social", em nítido conflito com a "teoria da ordem social", considerada pelo então reitor

\footnotetext{
4 Jasmin Beverwijk, "The Genesis of a System: Coallition Formation in Mozambican Higher Education, 1993-2003” (Tese de Doutorado, Universidade de Twente, 2005), p. 102.

5 Ganhão, "Problemas", pp. 5-17.
} 
da UEM como "uma das teorias mais reacionárias da ciência social burguesa". ${ }^{6}$ Para os dirigentes da FRELIMO, a gênese da teoria social, não deveria estar exclusivamente ligada ao estudo de texto, a salas de aulas, mas também a uma "prática e nas lutas sociais".?

Este contexto de falta de professores e pesquisadores, de ausência de cursos na área das Ciências Sociais e Humanas e de tentativa do novo poder de "tomar as rédeas" da moribunda universidade e de "revolucionar" a sua concepção de ensino e pesquisa (agora a serviço da maioria da população negra), desempenhou um papel crucial no surgimento da ideia da criação de uma área de ensino e pesquisa em Ciências Sociais no período pós-independência. Como afirmou Fernando Ganhão, primeiro reitor da "nova" universidade:

Não havia moçambicanos para os substituir. Fomos aos países socialistas com o intuito de encontrar pessoas para preencher essas lacunas. Primeiro nesses países porque eu próprio vinha de um país socialista, a Polônia, onde estava a fazer o meu doutoramento. No entanto, eu estava consciente das limitações que eles tinham em Ciências Sociais. Assim, não queria reproduzir esses modelos aqui em Moçambique; decidi então virar as atenções para a Universidade de Dar Es Salaam, onde encontrei no Centro de Pós-Graduação em Estudos de Desenvolvimento alguns pesquisadores, dentre os quais Marc Wuyts, a quem desafiei para ir trabalhar conosco a fim de se criar uma área de ensino em Ciências Sociais aqui na UEM. ${ }^{8}$

A ideia inicial do reitor de criar na universidade novos cursos na área das Ciências Sociais, em disciplinas, por exemplo, como Sociologia, Antropologia ou Ciências Políticas, iria ainda ter que esperar cerca de vinte anos. No entanto, começava-se já a cogitar na criação de algo em torno da pesquisa em História e, assim, aproveitar os poucos jovens estudantes moçambicanos finalistas daquele bacharelado da UEM. Como disse o reitor Fernando Ganhão:

Ganhão, "Problemas", pp. 5-17.

Ganhão, "Problemas", p. 8.

Entrevista com Fernando Ganhão, julho de 2007. 
Falei com várias pessoas. Convidei o dr. Aquino de Bragança, que era jornalista do Afrique-Asie, e contatei os meus estudantes do Bacharelado de História. Eu era então professor de História. Convidei alguns alunos, dentre os quais, o Luís de Brito, o Carlos Serra, a Teresa Cruz e Silva, a Isabel Casimiro e outros que já não me recordo. ${ }^{9}$ Enfim, todo aquele grupo de estudantes do Bacharelado. Foi nessa altura que me lembrei de fazer uma homenagem àquele Centro de Estudos Africanos de 1949 que foi criado em Lisboa por Amílcar Cabral, Agostinho Neto, Marcelino dos Santos e outros que se encontravam exilados [...] não teve uma vida longa, esse Centro em Portugal, mas a ideia era render uma homenagem, não obstante a sua curta duração. ${ }^{10}$

O CEA foi, então, formalmente criado na Universidade Eduardo Mondlane em janeiro de 1976, tendo como diretor Aquino de Bragança, o "nômada da luta anticolonialista", ${ }^{11}$ jornalista, acadêmico, professor e conselheiro pessoal do presidente Samora Machel. Um intelectual multifacetado profundamente engajado na luta dos povos oprimidos, na defesa da justiça social, e na apologia de um socialismo crítico e heterodoxo. Como muito bem observou Immanuel Wallerstein, Aquino de Bragança desempenhou três diferentes papéis na sua vida: o de militante, quando ainda jovem em Goa (Índia), e mais tarde, em Lisboa, Paris, Rabat e Argel, mergulhou profundamente no ativismo anticolonial a favor dos países africanos de expressão portuguesa, como jornalista radical $^{12}$ e como um elemento chave na criação (juntamente com nacionalistas africanos como Agostinho Neto, Amílcar Cabral e Marcelino dos Santos) da Conferência das Organizações Nacionalistas das Colônias Portuguesas (CONCP). Aquino de Bragança teve um papel preponderante na emergência dos movimentos de libertação nacional nes-

9 Na verdade houve aqui um lapso de memória de Fernando Ganhão, na altura da entrevista: os pesquisadores Carlos Serra e Isabel Casimiro não fizeram parte do primeiro grupo de jovens estudantes que fundaram o CEA. Entrevista realizada com Luís de Brito, março de 2010

10 Entrevista com Ganhão, março de 2007.

11 Depoimento de Pietro Petrucci, jornalista italiano, apud Sílvia Bragança, Aquino de Bragança: batalhas ganhas, sonhos a continuar, Maputo: Ndijira, 2009, p. 55.

12 Escreveu sob temas relacionados com os países africanos então colônias portuguesas nos jornais radicais, Revolution Africaine e Afrique-Asie, e que viriam a ter um grande impacto, numa primeira fase, na formação dos movimentos de libertação, e mais tarde numa maior consciencialização do mundo sobre a legitimidade da luta armada desses movimentos e das atrocidades do colonialismo português. 
sas colônias, como no sucesso das independências africanas. Marcelino dos Santos afirmara que "os primeiros fornecimentos de armas aos movimentos de libertação fizeram-se por intermédio de Aquino de Bragança, que organiza igualmente o apoio logístico aos movimentos de libertação". ${ }^{13}$

Em 1974, com o fim do colonialismo, Aquino de Bragança acabou sendo uma figura central nas negociações que levariam aos acordos de Lusaka, em que Portugal reconheceu a independência de Moçambique governado pela FRELIMO. Estávamos, então, em presença de outro papel de Aquino de Bragança, o de diplomata. Devido a sua integridade e compromisso com a luta anticolonial, ele tinha conquistado a confiança dos líderes da FRELIMO e especialmente do presidente Samora, tendo sido, em outras ocasiões, chamado para missões diplomáticas em várias partes do mundo. Depois da independência em 1975, com a FRELIMO no poder,

Samora logicamente disse: Aquino vamos para casa e ele naturalmente veio para casa. E ele me disse uma vez que nunca na vida ele sentiu que não estivesse em casa dele aqui. ${ }^{14}$ Sentiu-se sempre parte desta comunidade, da comunidade da FRELIMO e também da própria comunidade aqui, porque já tinha cá estado no período colonial e tinha também amigos que não eram da FRELIMO.$^{15}$

Aquino de Bragança veio, então, definitivamente para Moçambique em 1975, onde "Samora Machel deu-lhe muitas posições e ele apenas requereu uma: a criação do CEA". ${ }^{16}$ Não nos parece importante, aqui, averiguar de quem, de fato, surgiu a ideia de criar o CEA (Fernando Ganhão ou Aquino de Bragança?). Importa, sim, ter-se em consideração os vários contextos sociais em que se tornou possível o surgimento desta instituição de pesquisa e ensino. O contexto internacional das lutas de libertação nacional, o contexto da independência nacional de

\footnotetext{
13 Marcelino dos Santos, "Elogio Funebre", Research Bullet (1987), p. 6.

14 Aquino de Bragança nasceu em 1928 em Goa, Índia.

15 Entrevista com José Luís Cabaço, setembro de 2009

16 Immanuel Wallerstein, "Southern Africa and the World- Economy", Research Bulletin, Fernand Braudel Center for Study of Economics, Historical Systems, and Civilizations, Binghamton: State University of New York Press, (1987), pp. 1-5.
} 
Moçambique, do controle do poder do Estado por um grupo político que se pretendia revolucionário e engajado na construção da alternativa socialista no país e na África Austral. Um grupo político engajado na transformação radical das condições sociais da população, dando ênfase particular ao papel da ciência na transformação das mentalidades, na construção de uma nova historiografia moçambicana livre da visão de mundo colonial, e no uso da ciência para a revolução social e econômica.

No primeiro ano do CEA, a equipe de pesquisadores era constituída por uma geração de jovens historiadores moçambicanos, que tinham sido recrutados do bacharelado de História na Universidade Eduardo Mondlane: Luís de Brito, Eulália de Brito, Miguel da Cruz, Ana Loforte, Teresa Cruz e Silva, Salomão Nhantumbo, António Pacheco, Amélia Muge, Nogueira da Costa, João Morais e Ricardo Teixeira. Este grupo não foi constante no Centro. Alguns permanecem, mas outros foram transferidos para diversas instituições de ensino como docentes, ou mesmo para outros lugares de pesquisa, em grande parte devido a solicitações do governo para responder aos grandes desafios da reconstrução nacional.

O CEA estava, nesse primeiro momento da sua criação, exclusivamente voltado à pesquisa da História Colonial de Moçambique, dividida em seções, cada uma representando diferentes períodos históricos. Os pesquisadores Luís de Brito, Eulália de Brito, António Pacheco e o próprio diretor do Centro, constituíam o grupo de pesquisa da África Austral, uma vez que Aquino de Bragança colocara logo a necessidade de olhar Moçambique no seu contexto regional. Nogueira da Costa e Miguel da Cruz constituíram o grupo de História do século XIX, particularmente das companhias majestáticas; Ana Loforte, Salomão Nhantumbo e Amélia Muge constituíram o grupo de Antropologia, e os restantes estudantes/pesquisadores ficaram na Arqueologia. Estas áreas do CEA estavam mais direcionadas para a pesquisa documental e com muito pouca atenção à pesquisa de campo no interior das comunidades.

Esta foi, portanto, a estrutura inicial do Centro, em que, nos seus primeiros três anos de funcionamento, era composto maioritariamente por jovens pesquisadores moçambicanos. No entanto, foram, primeiro, aparecendo pesquisadores internacionalistas, como Kurt Mandorin, 
Barry Munslow, Marc Wuyts e David Wield. Alguns destes tinham sido inicialmente recrutados para ensinar no idealizado curso de Ciências Sociais, desenhado pelo reitor Fernando Ganhão. Porém, como este projeto não se concretizou, estes pesquisadores foram gradualmente integrados ao CEA como colaboradores.

Foi com esta composição que o CEA levou a cabo, em 1976, a sua primeira pesquisa coletiva, "Zimbabwe: a questão rodesiana", um estudo encomendado pelas estruturas do poder e que pretendia auxiliar o governo moçambicano e os revolucionários da ZANU $(\mathrm{PF})^{17}$ a perceber melhor o tipo de desafios, tensões e contradições que poderiam emergir no processo da negociação da independência do Zimbabwe, que iria decorrer nesse mesmo ano em Genebra. ${ }^{18}$

O projeto foi elaborado e investigado e o relatório coletivamente ${ }^{19}$ escrito num curto período de três semanas. ${ }^{20} \mathrm{O}$ estudo, utilizando a perspectiva de análise marxista, procurou compreender o desenvolvimento das estruturas coloniais econômicas da Rodésia com o objetivo de distinguir as diferentes classes sociais e facções de classe que emergiram da base colonial. Pretendiam ainda identificar as prováveis posições que estas classes poderiam tomar naquela fase da luta no Zimbabwe. ${ }^{21}$ Neste relatório, os pesquisadores do CEA examinaram questões candentes para a fase de transição para a independência do Zimbabwe,

\footnotetext{
17 Zimbabwe African National Union (Patriotic Front).

18 As conversações começaram em Genebra, Suíça, em outubro de 1976, entre o governo de Ian Smith e os partidos nacionalistas. Os nacionalistas estavam divididos, apesar dos esforços do presidente dos estados da "Linha da Frente" para uni-los. Os dois principais líderes nacionalistas, Joshua Nkomo e Robert Mugabe tinham, no entanto, formado, nesse mesmo mês, a aliança política "Frente Patriótica". Ndabaningi Sithole e Abel Muzorewa, líderes dos outros partidos, participaram na conferência separadamente. Ian Smith, líder do governo minoritário branco da Rodésia, insistia que o propósito da Conferência fosse o de implementar as propostas de Henry Kissinger, então secretário de Estado dos EUA, que incluíam controle branco da defesa, da lei e ordem. Os nacionalistas rejeitaram logo de início essas propostas. Ivor Richard, o embaixador britânico nas Nações Unidas, presidiu a Conferência que durou 7 semanas. As conversações foram adiadas para dezembro, contudo nunca mais foram recomeçadas. Ver Gwyneth Williams e Brian Hackland, The Dictionary of Contemporary Politics of Southern African, London: Routledge, 1988.

19 Participaram deste projeto oito pesquisadores do CEA: Aquino de Bragança, Maria Eulália Brito, Luís de Brito, Kurt Mandorin, Barry Munslow, António Pacheco, David Wield e Marc Wuyts.

20 CEA, A questão rodesiana, Lisboa: Iniciativas Editoriais, 1978.

21 CEA, A questão rodesiana.
} 
nomeadamente a importância do investimento estrangeiro na Rodésia, a questão da terra, a dimensão, a composição e o caráter da classe operária e inferências sobre o seu papel revolucionário na fase de transição para a independência. Traziam ainda alguns dados sobre a pequena burguesia africana e a população colona, como forma de empreender uma análise mais atual da sua heterogeneidade e potencial para o Zimbabwe pós-independência.

Este relatório mudou de forma decisiva a dinâmica de investigação em Ciências Sociais no pós-independência, introduzindo uma pesquisa (coletiva) que se preocupava com assuntos candentes e urgentes da realidade moçambicana no contexto da África Austral. ${ }^{22}$ Com esta empreitada científica, a antiga divisão do CEA em temas da história dos séculos XVIII e XIX deixou de fazer sentido. Os pesquisadores estavam agora mais absorvidos em fazer pesquisa coletiva, urgente, e que respondessem aos desafios da atualidade.

O CEA ganhou uma nova dinâmica em 1977, um ano depois da sua criação, com a chegada de Ruth First, ${ }^{23}$ que veio inicialmente para dirigir a pesquisa sobre o fluxo de mão de obra migrante moçambicana para as minas da África do Sul. Nascia, assim, a obra $O$ mineiro moçambicano: um estudo sobre a exportação de mão de obra. Este estudo acabou se tornando a obra de referência do CEA. ${ }^{24}$ Após a conclusão da pesquisa, Ruth First foi nomeada, em 1979, para o cargo de diretora científica do CEA. A partir daí ela iria dirigir, com "braço de ferro", a

22 Este argumento é baseado na entrevista que fiz com Marc Wuyts, em julho de 2009. Para uma leitura mais detalhada sobre este Relatório de Investigação como também da emergência desta nova forma de fazer pesquisa no CEA, ver Carlos Fernandes, "Dinâmicas de pesquisa em Ciências Sociais: o caso do CEA - 1975-1990" (Tese de Doutorado, Universidade Federal da Bahia, 2011), p. 284.

23 Ruth First, sul-africana, jornalista, pesquisadora, professora e ativista política anti-apartheid, membro do CNA e do Partido Comunista Sul-Africano. A sua entrega à causa das lutas de libertação nacional nos países da África Austral, o seu compromisso com a luta antiimperialista e rigor na pesquisa científica iria ter um grande impacto na vida do CEA, marcando profundamente toda uma geração de jovens cientistas sociais moçambicanos. Foi assassinada, com uma carta-bomba, pelos serviços secretos da África do Sul, em agosto de 1982, no seu escritório no CEA.

24 Para uma leitura mais atenta sobre este projeto de pesquisa (publicado em Moçambique, em 1978, em livro com o titulo: O mineiro moçambicano: um estudo sobre a exportação de mão de obra), vide Fernandes, "Dinâmicas". 
maior parte da pesquisa científica do Centro. ${ }^{25} \mathrm{~A}$ antiga estrutura do CEA, focalizada fundamentalmente na história dos séculos XVIII e XIX de Moçambique, começou então a perder a posição de destaque.

Havia agora três principais grupos de interesse. O Núcleo de Estudos da África Austral, um grupo de pesquisa centrado na análise contemporânea da situação política e econômica da região da África Austral, com particular ênfase nas dinâmicas internas da luta do Congresso Nacional Africano (CNA), e a análise política, econômica e da desestabilização militar da África do Sul na região. Havia ainda o curso de pósgraduação em Desenvolvimento, mais conhecido como Curso de Desenvolvimento.

O primeiro esboço deste grande projeto de ensino/pesquisa foi desenhado por Ruth First, Marc Wuyts e David Wield (em consulta com Aquino de Bragança), logo após a conclusão da obra $O$ mineiro moçambicano. O Curso tinha sido inicialmente concebido como mestrado, no entanto, verificou-se que não havia candidatos suficientes com licenciatura para preencher as vagas disponíveis. De acordo com Marc Wuyts, a fraca adesão ao Curso deveu-se ao legado educacional colonial que havia sido extremamente limitado para os moçambicanos negros. Luís de Brito traz-nos, no entanto, uma outra leitura para a fraca aderência de candidatos da Faculdade de Letras (Linguística, Geografia e História). Segundo Luís de Brito, os docentes desta faculdade "não viam com bons olhos" este novo curso, uma vez que prevalecia na altura a ideia de que o CEA possuía uma abordagem demasiado economicista. $^{26}$

Foi a partir destes obstáculos que Ruth First pensou em algo mais "revolucionário". Um curso que pudesse congregar alunos com vários níveis acadêmicos a partir do nível secundário, $9^{\text {a }}$ classe. Os alunos do Curso iriam, portanto, ser recrutados em diversos setores da sociedade, do governo, ministérios, governos provinciais, forças armadas, FRELIMO,

\footnotetext{
${ }^{25}$ Segundo Dan O’Meara, apesar da sua "personalidade difícil", a competência profissional e sentido de liderança de Ruth First no Centro tinha deixado Aquino de Bragança sem nenhum papel significativo na definição, organização, administração da pesquisa. Entrevista com Dan O'Meara, 2007.

${ }^{26}$ Entrevista com Luís de Brito, março de 2010.
} 
imprensa, universidade. $\mathrm{O}$ foco passou então à formação de pessoal diretamente envolvido nas tarefas de construção do socialismo em Moçambique. Paralelamente a este componente de ensino, que compreendia a aquisição de conhecimentos sobre economia política, o Curso tinha um componente de pesquisa muito forte. A pesquisa, para o CEA, não era vista como um empreendimento acadêmico, tendo lugar somente em laboratórios, em círculos exclusivos. Pesquisa social, para os membros do Centro, significou o estudo e análise da realidade social do país. Significou, por exemplo, o estudo das condições da produção nas machambas ${ }^{27}$ estatais mas também familiares, nas cooperativas, dentro de unidades de produção industriais.

Em último lugar havia um terceiro grupo, a Oficina de História, criado em 1980 pelo diretor do Centro, Aquino de Bragança, voltado para o resgate da experiência histórica da luta de libertação nacional, e para produção de pesquisa histórica sobre Moçambique contemporâneo. Este coletivo de pesquisa histórica fundou em 1983 a Não Vamos Esquecer!, uma revista de periodicidade irregular e que teve apenas quatro edições. Em 1980, havia já sido criada pelo CEA a revista semestral de Ciências Sociais, Estudos Moçambicanos, que pretendia pensar Moçambique no contexto da África Austral.

\section{A emergência de tensões e diferentes interesses de pesquisa}

Um dos objetivos principais desta seção é demonstrar que o CEA não foi uma entidade homogênea e monolítica; embora tenha partilhado valores e características comuns, foi também um espaço de lutas e de diferentes interesses e prioridades de pesquisa.

Durante as entrevistas com os pesquisadores do CEA, um ponto recorrentemente referido por eles, quando perguntados sobre questões de liderança no Centro, foi a relação de complementaridade, mas também de ambiguidade, entre o diretor Aquino de Bragança e Ruth First, diretora científica. Para a maioria dos entrevistados, o "motor" do CEA era encarnado pela figura de Ruth First. Foi recorrentemente apontada

${ }^{27} \mathrm{O}$ mesmo que farma ou herdade para cultivo. 
a sua capacidade de liderança e de organização do trabalho de pesquisa e ensino. Dan O'Meara, pesquisador sul-africano, que juntou-se em $1981^{28}$ ao Núcleo de Estudos da África Austral, por exemplo, afirmou que "todos no CEA, incluindo Aquino, claramente perceberam que era a Ruth First quem comandava o lugar, quem tomou quase todas as decisões e quem angariava a maior parte do dinheiro para financiar os trabalhos do CEA". ${ }^{29}$

Ana Maria Gentili, historiadora italiana, foi uma das pesquisadoras e docentes do Centro que destacou a sua capacidade de liderança:

Ruth First era uma pessoa que tinha uma grande qualidade de pesquisadora, jornalista e uma grande capacidade de investigação e de organização. Com ela não se brincava, tinhas que demonstrar que eras bom pesquisador, que tinhas tudo terminado dentro dos prazos. ${ }^{30}$

É ainda Teresa Cruz e Silva quem não deixa de reconhecer o valor que teve a presença de Ruth First no CEA: "com Ruth First nós aprendemos o método, como trabalhar, como interrogar [...] ela era organizada, metódica, sistemática, exatamente o oposto de Aquino de Bragança". ${ }^{31}$

No entanto, os entrevistados não deixaram de relacionar a sua personalidade "forte" com o aparecimento de ressentimentos e tensões entre os pesquisadores do Centro, e com outros departamentos de pesquisa e ensino da UEM. A propósito, Teresa Cruz e Silva afirmou que "havia uns certos conflitos por causa da personalidade dela. Ruth First, com aquele seu feitio e aquela sua maneira de comando, não aceitava muito bem as pessoas da Faculdade de Letras, como também da Faculdade de Economia". ${ }^{32}$

É de se referir que este artigo não se propõe a explicar o trabalho de Ruth First no CEA em termos psicológicos, mas tão somente enfatizar

\footnotetext{
8 O'Meara referiu que tinha sido convidado, em 1979, por Ruth First para trabalhar no CEA, mas devido aos seus compromissos acadêmicos na Universidade de Dar es Saalam, na Tanzânia, só viria a fazer parte do CEA em 1981.

29 Entrevista com Dan O'Meara, agosto, 2007.

30 Entrevista com Ana Maria Gentili, junho de 2007.

31 Entrevista com Teresa Cruz e Silva, agosto de 2007.

32 Entrevista com Teresa Cruz e Silva, agosto de 2007.
} 
que diante desta figura estavam de fato duas "agendas" distintas: uma política (devido a sua ligação com o "núcleo duro" do CNA e do partido comunista sul-africano) e outra científica (como professora, pesquisadora e diretora científica do CEA). João Paulo Borges Coelho sintetizou de forma esclarecedora a influência destas duas personas:

Dentro do CEA vão-se criando tensões quando chega Ruth First em meados de 79. Quando ela chega, ela entra como investigadora para montar um projeto, mas que ela há-de ter trazido também uma agenda própria relativamente a este núcleo acadêmico do CNA que se criou aqui. Era uma espécie de atividade de contra-inteligência ou de investigação da situação a partir de um ponto de observação muito mais próximo da África do Sul. ${ }^{33}$

Ruth First acreditava que o seu trabalho na direção da pesquisa no CEA iria também contribuir para a luta do CNA, não somente com a produção de conhecimento científico politicamente relevante, acreditando que a compreensão da situação política na sociedade sul-africana seria vital para o sucesso do socialismo em Moçambique, mas também com a convicção de que a experiência dos moçambicanos de gerirem um país soberano seria instrutivo para outros membros do CNA, quando finalmente libertassem seus países do jugo colonial. Essa foi uma das razões para a dinamização do Núcleo de Estudos da África Austral, que iria também produzir "inteligência política" para o CNA. ${ }^{34}$ Dan O'Meara aludiu ainda ao trabalho politicamente engajado de Ruth na construção do socialismo em Moçambique:

Nós estávamos em Londres, numa confraternização para celebrar o $70^{\circ}$ aniversário de Yussuf Dadoo, na altura secretário-geral do Parido Comunista sul-africano. Joe Slovo e Ruth First estavam lá. Ruth chamoume à parte e perguntou-me se eu estava interessado em vir trabalhar para o CEA. Ela explicou que tinha o apoio do presidente Machel e do vice-presidente, Marcelino dos Santos, e que o entendimento da políti-

\footnotetext{
33 Entrevista com João Paulo Borges Coelho, agosto de 2007.

34 Durante a entrevista, O’Meara mencionou que muitas das pesquisas realizadas pelo Núcleo eram usadas como fonte nos debates e discussões dentro do CNA sobre a evolução da sociedade sul-africana e, particularmente, as reformas a serem introduzidas pelo governo de P. W. Botha. Entrevista com Dan O’Meara, julho de 2007.
} 
ca e da sociedade sul-africana era vital para o sucesso do socialismo em Moçambique. ${ }^{35}$

No seu trabalho de direção da pesquisa, e principalmente do Curso de Desenvolvimento, Ruth First confiou quase totalmente num pequeno "círculo interno" de pesquisadores do CEA. Três destes se destacam: o macro-economista belga Marc Wuyts, que, como disse Luís de Brito, era "a alma teórica do Centro", ${ }^{36}$ a antropóloga americana Bridget O’Laughlin, e o sociólogo alemão Kurt Habermeier. No entanto, este último iria deixar o CEA mais cedo, nos princípios dos anos 1980. Marc Wuyts e Bridget O'Laughlin eram de fato a grande influência intelectual de Ruth First. Quer dizer, enquanto Ruth First fornecia a linha política e a disciplina (muito do respeito nutrido por ela advinha disso), a análise da sociedade moçambicana vinha fundamentalmente de Marc Wuyts e Bridget O'Laughlin. Marc Wuyts fornecia um entendimento coerente sobre a evolução econômica de Moçambique e os problemas criados pela economia colonial, como pelas políticas da FRELIMO. Bridget O'Laughlin proporcionava a Ruth First um entendimento convincente de como a sociedade rural funcionava. Era então o "trio" ${ }^{37}$ Ruth/Marc/Bridget que, em última instância, decidia sobre a natureza da pesquisa e ensino que o CEA deveria desenvolver, principalmente no que concernia ao Curso de Desenvolvimento. Ruth First deu a estes dois pesquisadores uma nítida preeminência e neles confiava plenamente. Como afirmou Isabel Casimiro, "os temas a pesquisar eram discutidos por todos, mas era o "núcleo duro"" quem dirigia. ${ }^{38}$

Um segundo grupo de interesse, a Oficina de História, esteve organizado à volta de pessoas como Aquino de Bragança, o historiador congolês Jacques Depelchin, Ana Maria Gentili, o pesquisador brasileiro Valdemir Zamparoni e o grupo dos jovens historiadores moçambicanos Luís de Brito, Teresa Cruz e Silva, Marco Teixeira, Yussuf Adam,

\footnotetext{
35 Entrevista com Dan O’Meara, agosto de 2007.

36 Entrevista com Luís de Brito, março de 2010.

37 Poderíamos ainda acrescentar a agrônoma inglesa Helena Donly, não obstante ela ter chegado ao Centro muito mais tarde, em 1980. Donly também proporcionou a Ruth First, um melhor entendimento da agricultura em Moçambique.

38 Entrevista com Isabel Casimiro, agosto de 2007.
} 
Alexandrino José e Isabel Casimiro. Este grupo procurava afastar-se do controle de Ruth First, já que alguns destes pesquisadores achavam que Ruth First abusava do seu poder e se ressentiam da sua atitude em relação ao Aquino de Bragança. Como afirmou Judith Head, "Ruth não queria saber da Oficina de História, o seu trabalho era o Curso de Desenvolvimento". ${ }^{39}$

A criação da Oficina de História pode ser lida, deixando de lado o seu principal objetivo de restaurar a dignidade histórica dos moçambicanos, como uma forma de Aquino de Bragança garantir um espaço de manobra (fora da alçada de Ruth), na direção e definição dos objetos de pesquisa do Centro. No mesmo diapasão, os pesquisadores do Núcleo de Estudos da África Austral, que sob iniciativa de Ruth First produziram "dossiers" sobre a análise política na África Austral para serem distribuídos aos membros do governo, lutavam constantemente para adquirir um espaço próprio, livre do comando de First, e onde pudessem desenvolver outro tipo de abordagens sobre África Austral, com particular incidência para as questões sul-africanas.

O terceiro e último grupo constituído por pesquisadores como Robert Davies, Dan O'Meara, Sipho Dlamini, Gottfried Wellmer e Alpheus Manghezi e Yussuf Adam era o Núcleo de Estudos da África Austral. A principal luta desse grupo estava relacionada com a garantia/ manutenção de um espaço de pesquisa próprio e que não estivesse sob o controle de Ruth First. O depoimento de Dan O'Meara é elucidativo desta tensão:

Nós sentíamos [Núcleo de Estudos da África Austral] que Ruth não seguia as questões políticas sul-africanas tão profundamente como nós seguíamos e que o entendimento dela sobre alguns aspectos da luta na África do Sul não estava atualizado, o que se resumia em repetir uma linha política em vez de uma análise detalhada da evolução de vários aspectos da luta dentro da África do Sul. ${ }^{40}$

Muito embora seja possível encontrar características comuns entre os pesquisadores do CEA, como, por exemplo, a produção de co-

\footnotetext{
39 Entrevista com Judith Head, agosto de 2007.

40 Entrevista com Dan O'Meara, julho de 2009.
} 
nhecimento socialmente relevante para a construção do socialismo em Moçambique e total libertação da África Austral da dominação do sistema capitalista e segregacionista da África do Sul, este Centro não formou um grupo unificado ou mesmo homogêneo. E é exatamente neste ponto que este artigo se distancia da perspectiva do antropólogo francês Christian Geffray, que, estando em Moçambique em 1986, escreveu um artigo sobre o CEA em que argumentava que este tinha funcionado como um órgão intelectual do poder e que, através das suas investigações sobre o campesinato moçambicano, "caucionava" cientificamente as diretrizes políticas da FRELIMO. ${ }^{41}$ Este tema será retomado na seção seguinte.

\section{Intelectuais orgânicos e legitimação do Estado}

Esta seção examina a conexão entre o trabalho científico do CEA e a manutenção e legitimação da visão de mundo da FRELIMO durante o período de 1975 a 1984. Esta conexão será estabelecida a partir da delineação das principais linhas de investigação do Centro vis-à-vis o programa político do partido no poder. Em seguida serão escolhidos alguns dos relatórios científicos como forma de mostrar, mais uma vez, a sua profunda ligação e coerência com as prioridades políticas do Estado para a transformação socialista. Contudo, antes de entramos nesta análise, iremos por ora desenhar em traços gerais o contexto histórico em que se vão estabelecer estas conexões entre produção científica e legitimação do Estado.

\section{O contexto histórico}

Nos primeiros anos pós-independência, a FRELIMO acreditou que estava se movendo de uma vitória para outra. Um mês depois da independência nacional, o sistema judicial, a medicina, a educação e os serviços funerários tinham sido nacionalizados. ${ }^{42}$ Foi neste período que a

\footnotetext{
${ }^{41}$ Christian Geffray, "Fragments dun discours du pouvoir (1975-1985): Dun bon usage d'une meconnaissance scientifique", Politique Africaine, n. 29 (1988), pp. 71-87.

42 Joseph Hanlon, Mozambique: The Revolution Under Fire, Londres: Zed Books, 1984, p. 46. 
política de estatização da FRELIMO se tornou mais acelerada e tentou eliminar a maior parte das empresas privadas, congelando as suas contas bancárias. ${ }^{43}$ Apesar de ter herdado a economia em bancarrota e com um défice crônico na balança de pagamentos, nos primeiros cinco anos depois da independência nacional a FRELIMO conseguiu alcançar progressos significativos na educação, saúde e habitação, tendo sido por exemplo proclamado pela Organização Mundial da Saúde (OMS), em 1981, que o seu sistema de cuidados de saúde e prevenção era um modelo para os países do terceiro mundo. ${ }^{44}$

No campo político aconteceram grandes mudanças com a transformação da única força política na sociedade, ${ }^{45}$ a FRELIMO, em "partido de vanguarda marxista-leninista" no seu $3^{\circ}$ congresso em 1977. O partido FRELIMO, a "força dirigente da sociedade e do Estado", deveria então guiar, mobilizar e organizar as massas na tarefa de construir uma democracia popular, "rumo ao socialismo". As suas principais diretrizes políticas para o desenvolvimento socialista estavam refletidas nas deliberações do histórico $3^{\circ}$ congresso, que

[...] estabeleceu a linha estratégica do desenvolvimento de Moçambique. Nesta estratégia a agricultura é a base e a indústria o fator dinamizador e decisivo. Isto implica que numa primeira fase a agricultura constitua a principal fonte de acumulação para o desenvolvimento econômico. Isto significa que a socialização - a extensão e consolidação do setor estatal e a cooperativização de produção familiar - é uma tarefa imediata e imperativa. ${ }^{47}$

No setor econômico, a fuga maciça dos portugueses, que ocorre-

\footnotetext{
${ }^{43}$ Ver Thomas Henriksen, Mozambique: A History, Cape Town: Rex Collings, 1978.

${ }_{44}$ Hanlon, "Mozambique", p. 82.

45 A distinção entre partido e Estado não existia. A FRELIMO era a única força política na sociedade. O partido trabalhou incessantemente para entrar e controlar todos os setores da sociedade. Assim, logo nos princípios de 1978, foram-se estabelecendo os "grupos dinamizadores", como também células do partido na universidade, nas fábricas, "aldeias comunais", escolas, ministérios etc., com o objetivo de garantir a implementação das orientações da FRELIMO, como também de romper com os métodos de trabalho do Estado colonial capitalista.

46 Teses do $3^{\circ}$ Congresso, citadas a partir do artigo de Thomas Henriksen, "Marxism and Mozambique", African Affairs, v. 77, n. 309 (1978), p. 459.

47 Estudos Moçambicanos, n. 2, UEM, CEA (1981), p. 2.
} 
ra a partir do fim do salazarismo, em 1974, levou ao colapso de setores vitais da economia, como o comércio e a produção de culturas alimentares e a rede de distribuição rural, e não somente houve uma fuga de capitais, mas também o que podia ser visto como uma consciente e deliberada sabotagem foi levada a cabo. ${ }^{48}$ Começou-se gradualmente a verificar o colapso do mercado, particularmente nas trocas comerciais entre o setor rural e urbano, afetando sobremaneira a produção do campesinato e o abastecimento em gêneros industriais, uma vez que o Estado passava agora a privilegiar as machambas estatais, representando o "polo de desenvolvimento", acreditando que a transformação rural seria mais efetiva através do setor público. ${ }^{49}$ Para a FRELIMO, o setor moderno da agricultura viria com o incremento das machambas estatais em oposição ao setor familiar, considerados nos primeiros cinco anos após a independência como "atrasado". Daí, então, sancionar políticas agrárias que não levavam em conta o papel do campesinato na produção.

Um outra grande inquietação destes primeiros cinco anos pósindependência foi o que fazer com a dependência da economia do sul de Moçambique em relação ao capital mineiro sul-africano. A preocupação do poder político resumia-se em avaliar se se deveria cortar ou não este fluxo migratório. Uma questão sensível para o governo moçambicano, uma vez que a grande maioria do operariado nacional era constituída pelos cerca de 140.000 mineiros que trabalhavam anualmente nas minas sul-africanas, sem contar ainda com aqueles que trabalhavam ilegalmente em outros setores da economia sul-africana. ${ }^{50}$ Foi assim que a FRELIMO decidiu manter o fluxo migratório, apesar do fato de que, em 1975, o governo sul-africano reduziu drasticamente o número de contratados para 40.000, concorrendo para o aumento do desemprego no sul de Moçambique. Como forma de responder a esta

\footnotetext{
${ }^{48}$ Plantações e maquinarias de irrigação foram deliberadamente destruídas, gado abatido e gêneros alimentícios disponíveis retirados do mercado com o intuito de criar uma escassez artificial. Ver, Sónia Kruks, "From Nationalism to Marxism: The Ideological History of Frelimo, 1962-1977", in Irving Markovitz (org.), Studies in Power and Class in Africa (Londres: Oxford University Press, 1987).

49 Vide, Merle Bowen, The State Against the Peasantry: Rural Struggles in Colonial and Postcolonial Mozambique, Charlottesville: University Press of Virginia, 2000.

50 Dan O'Meara, “The Collapse of Mozambican Socialism", Transformation, n.14 (1991), pp. $82-103$.
} 
crise, a FRELIMO tentou criar políticas agrárias que pudessem integrar muitos dos desempregados na economia rural através da construção das aldeias comunais (obrigando os camponeses a deixarem as suas $m a-$ chambas familiares, seus locais sagrados e de culto e a irem viver de forma comunal), cooperativas de produção e das machambas estatais. O descontentamento e desencantamento popular começavam já a despontar gradualmente no horizonte moçambicano.

As infraestruturas econômicas e sociais acabariam gravemente afetadas por um misto de deficiente gestão estatal, estrangulamento do tecido social causado pelas incursões armadas da Resistência Nacional Moçambicana (RENAMO) e, não menos importante, pelas cheias que assolavam principalmente a zona sul do país. O $4^{\circ}$ congresso da FRELIMO, realizado 1983, tinha como um dos principais objetivos tentar então corrigir as lacunas e os erros anteriores e prenunciar uma nova ênfase em projetos de pequena escala descentralizados e orientados para o mercado. ${ }^{51} \mathrm{O}$ congresso instruiu as instituições do Estado a darem maior apoio à cooperativa, aos setores familiar e privado. Foram tomadas novas medidas em relação, por exemplo, à questão agrária, quando a FRELIMO acabou reconhecendo que tinha cometido um erro grave ao subestimar o papel do campesinato dando todo o apoio ao setor estatal.

A FRELIMO decidiu então que a alocação dos recursos deveria se basear num pragmatismo econômico em vez de ser pautado exclusivamente pela ideologia. ${ }^{52}$ Por outro lado, acreditava que ao se virar para uma estratégia mais direcionada à abertura do mercado iria corrigir os desequilíbrios econômicos que resultaram dos erros políticos do passado. No entanto, já havia um grande descontentamento rural agravado pelos massacres às populações perpetradas pela RENAMO, o êxodo forçado das populações para as cidades e o aumento do desemprego urbano. Por volta do final de 1983, a guerra tinha reduzido a capacidade da FRELIMO para implementar as suas políticas de desenvolvimento socialista. A economia moçambicana mostrava sinais de colapso total,

\footnotetext{
51 Merle Bowen, "Beyond Reform: Adjustment and Political Power in Contemporary Mozambique", The Journal of Modern African Studies, n. 30 (1992), pp 255-79, 261.

52 Otto Roesch, "Economic Reform in Mozambique: Notes on Destabilization War, and Class Formation", Taamuli, Dar es Salaam (1989), apud, Bowen, "Beyond", p. 263.
} 
forçando o governo a negociar um "pacto de não agressão e boa vizinhança" com a África do Sul. Os Acordos de Nkomati seriam firmados em março de 1984, com a intermediação dos Estados Unidos, em que os sulafricanos comprometeram-se a limitar as atividades da RENAMO e Moçambique, por sua vez, a impedir o CNA de lançar as suas ações militares a partir do solo moçambicano (no entanto, foi permitida a presença diplomática do CNA em Maputo). ${ }^{53}$ Como forma de angariar apoio dos países ocidentais e ao mesmo tempo tentar deter o declínio econômico, Moçambique, na altura um dos países mais pobres do mundo e profundamente endividado ${ }^{54}$ acabaria filiando-se, em setembro de 1984, ao Fundo Monetário Internacional (FMI) e ao Banco Mundial. A partir daí foram introduzidas reformas econômicas e políticas que iriam culminar, entre os anos 1984-1990, com o fim da ideologia marxista-leninista, com a abertura para a economia de mercado e sistema multipartidário.

\section{Produção científico-social e legitimação do Estado}

Cabe-nos, em seguida, procurar perceber as conexões existentes entre esta "visão de mundo" do grupo dominante e o trabalho de pesquisa científica do CEA. Antes, porém, de nos debruçarmos sobre esta relação, iremos explanar melhor o nosso quadro conceitual.

Charles Kurzman e Lynn Owens ${ }^{55}$ apontam três principais abordagens no campo da sociologia dos intelectuais. Encontramos uma primeira que analisa os intelectuais como uma "classe-em-si-mesma" (classin-themselves). Seus proponentes seriam autores como Julien Benda, Alvin Gouldner ou mesmo Pierre Bourdieu. Uma segunda abordagem que concebe os intelectuais como sem-classe (classless), representada por Karl Mannheim, Edward Shills, Raymond Aron. Uma terceira e última perspectiva aborda os intelectuais como vinculados a uma classe

\footnotetext{
${ }_{53}$ Ver Barry Munslow, "Rethinking the Revolution in Mozambique", Race \& Class, v. XXVI, n. 2 (1984), p.15-31.

54 Em 1987, segundo dados do Banco Mundial (1989), Moçambique tinha um PIB per capita de 170 US\$, colocando-se na $9^{\circ}$ posição no ranking dos países mais pobres. Vide João Mosca, "Evolução da agricultura moçambicana no período pós-independência", Departamento de Economia Agrária e Sociologia Rural, Instituto Superior de Agronomia de Lisboa (1996), pp. 1-51.

${ }_{55}$ Kurzman e Owens, "The Sociology of Intellectuals", Annual Review of Sociology, v. 28 (2002), pp. $63-90$.
} 
(class-bound), e tem em Antonio Gramsci seu principal expoente, além de autores como Michel Foucault, Edward Said ou Jerome Karabel.

Foi privilegiada aqui a analítica de Antonio Gramsci porque nos permite ver nos pesquisadores do CEA não somente sua dimensão de "gestores da legitimação", ${ }^{56}$ mas também sua característica "revolucionária" ao questionar criticamente a ordem social vigente. De acordo com este autor, todos os seres humanos são potencialmente intelectuais, mas nem todos têm na sociedade a função de intelectuais. Para ele, há dois tipos de intelectuais: o "tradicional" e o "orgânico". Gramsci identifica os eclesiásticos como a forma mais típica de intelectual tradicional, que são organicamente ligados a aristocracia latifundiária. Outro tipo de intelectual tradicional é o rural, uma categoria que inclui os eclesiásticos, advogados, notários e professores. Os intelectuais orgânicos, por sua vez, são aqueles que se engajam na participação ativa da vida prática, como construtores, organizadores e persuasores permanentes. De acordo com Gramsci, eles são "orgânicos" porque estão ligados a uma classe social ou um modo de produção específico. ${ }^{57}$

Este artigo usa uma definição não restrita do conceito de classe. Assim, a classe social a que pertencem todos os pesquisadores do CEA é a "classe dirigente", que segundo Georges Balandier, é "a única classe bem constituída em África" e que se define "pelo acesso e a luta em torno do poder" ${ }^{58}$ Esta definição ampliada de intelectual orgânico irá permitir lidar com a composição social heterogênea dos pesquisadores do CEA, que como vimos, depois da nomeação de Ruth First como diretora científica, acabou tendo mais pesquisadores de outros países que moçambicanos. E estes expatriados não se consideravam de alguma forma, por exemplo, como parte da classe proletária moçambicana.

56 Robert Fatton, "Gramsci and the Legitimization of the State: The Case of the Senegalese Passive Revolution” Canadian Journal of Political Science, v.19, n.4 (1986), p. 735.

57 Leonardo Salamini, "Gramsci and Marxist Sociology of Knowledge: An Analysis of HegemonyIdeology-Knowledge”, The Sociological Quarterly, v. 15, n. 3 (1974), pp. 359-80.

58 Georges Balandier, "Problematique des classes sociale en Afrique noire", Cahier Internationaux de Sociologie, n. XXXVIII (1965), p. 141, apud, Valdemir Zamparoni, "Entre Narros \& Mulungos: colonialismo e paisagem social em Lourenço Marques c. 1890-c.1940" (Tese de Doutorado, Universidade de São Paulo, 1998), p. 582. Neste estudo, Zamparoni reserva um capítulo para discutir, de forma minuciosa, os eixos centrais na grande discussão em torno da ideia de classe que, segundo ele, tem envolvido não só pesquisadores como também políticos. 
A "organicidade" desses intelectuais, ou por outra, a sua vinculação de classe só pode ser melhor percebida se tivermos em conta três diferentes contextos. Primeiro, o contexto internacional da luta antiimperialista e da polarização do mundo em dois blocos ideológicos antagônicos (socialismo/capitalismo); segundo, o contexto da África Austral e das lutas de libertação nacional de países como Namíbia, Zimbabwe e África do Sul e, por último, o contexto nacional da construção da alternativa socialista em Moçambique, liderada por um Estado que se pretendia revolucionário, engajado na transformação social e no uso da ciência para a revolução social. Foram alguns destes fatores que atraíram muitos intelectuais e pesquisadores progressistas e de "esquerda" de várias partes do mundo, como foi o caso dos pesquisadores expatriados do CEA. Como afirmara Ana Maria Gentili,

Nós fomos a geração da descolonização. Éramos todos idealistas e progressistas, no sentido de pensar que o conteúdo das independências não era só a liberdade política, não era somente de transformar indivíduos em cidadãos mas era também a justiça social. ${ }^{59}$

Como podemos notar a partir da tabela 1 apresentada, o tema da "transformação" teve grande centralidade nos relatórios de investigação do CEA. Assim, dos cerca de trinta e um relatórios produzidos no âmbito do Curso de Desenvolvimento, nove ${ }^{60}$ incluíam nos seus títulos o termo "transformação". Na sua maioria, estas pesquisas discutiram a transformação das antigas formas de produção inerentes à economia colonial em novas formas baseadas em modelos de produção socialista através, por exemplo, da introdução das machambas estatais e da dinamização do movimento cooperativo no campo. Não podemos deixar de lembrar que a FRELIMO, no seu $3^{\circ}$ Congresso (1977), tinha definido a "agricultura como a base e a indústria como o fator dinamizador para o desenvolvimento da economia moçambicana". ${ }^{61}$ Este processo de trans-

\footnotetext{
59 Entrevista com Ana Maria Gentili, junho 2007.

${ }^{60}$ CEA, "A transformação da agricultura familiar na província de Nampula", 1980; "Problemas de transformação rural na província de Gaza”, 1980 (Restrito); “Já não batem: a transformação da produção algodoeira”, 1981; "O papel dinamizador da Emochá na transformação socialista da Alta Zambézia", (1982); e por último, "Porto de Maputo: zona de contentores: informação, trabalho administrativo e a transformação do trabalho produtivo", 1983.

${ }^{61}$ FRELIMO, "III Congresso do Partido Frelimo", Directivas Económicas Sociais, Maputo: FRELIMO, 1977, pp. 1-12.
} 
Tabela 1. Principais linhas de pesquisa - Curso de Desenvolvimento (1979-1982)

\begin{tabular}{lc}
\hline Linhas de investigação & $\mathrm{N}^{\mathrm{o}}$ de relatórios \\
\hline Aldeias comunais & 2 \\
Comercialização agrária & 3 \\
Cooperativas & 4 \\
Algodão & 7 \\
Trabalho migratório & 2 \\
Transformação rural & 9 \\
Transportes & 4 \\
Total & 31 \\
\hline
\end{tabular}

formação das relações de produção implicou responder a vários objetivos que foram tidos como prioridades de pesquisa no CEA: a coletivização da produção através da transformação do setor familiar num setor cooperativo e a expansão do setor das machambas estatais; a reorganização espacial das unidades de produção e de formas de assentamento através da organização de aldeias comunais; melhoria das condições de vida da população, organizando cuidados e serviços de saúde, melhoria da habitação, fornecimento de água, de eletricidade.

Os pesquisadores do CEA eram "orgânicos" à classe dirigente no sentido que eles se constituíam como produtores de um conhecimento científico-social aplicado, que não só iria auxiliar o governo a alcançar os seus objetivos como a justificar as suas opções perante a sociedade, e lutavam para tornar a classe dirigente a que pertenciam hegemônica na sociedade, através, por exemplo, da difusão dos resultados das suas pesquisas nas revistas Estudos Moçambicanos e Não Vamos Esquecer!, bem como nos vários Relatórios de Investigação destinados aos membros do governo e funcionários do Estado. Assim, como forma de melhor servir aos objetivos do Estado, os pesquisadores do CEA procura- 
ram aliar suas prioridades de pesquisa às prioridades políticas da FRELIMO para o desenvolvimento socialista de Moçambique. Daí então a produção de estudos focalizados, alguns destes produzidos no âmbito do Curso de Desenvolvimento e outros diretamente solicitados por vários órgãos do Estado, como ministérios, direções nacionais, presidência da república etc. O trabalho intelectual do CEA tornou-se, assim, subsidiário da configuração socioeconômica do projeto hegemônico frelimista, e não o reverso. E foi precisamente nesta ligação entre trabalho intelectual e "revolução" que residiu a maior parte das críticas de alguns acadêmicos, principalmente do antropólogo francês Christian Geffray. ${ }^{62}$

A crítica de Geffray repousava em dois principais pontos. Primeiro, que o discurso científico do CEA sobre a existência social do campesinato era "teoricamente duvidosa" ${ }^{63}$ porque os pesquisadores do Centro não tinham levado em consideração as especificidades culturais do campesinato, olhando para eles como uma massa homogênea. Segundo, que a existência social do campesinato também era "politicamente duvidosa" ${ }^{64}$ Para Geffray, o trabalho do CEA (que ele via como um "órgão do estado") subordinou-se ao discurso do poder, com o principal propósito de legitimar, cientificamente, a ideologia da FRELIMO na construção e organização socialista da nação. Como afirmou Christian Geffray, o CEA aceitou o discurso oficial que acreditava na existência em Moçambique de uma "classe camponesa".

No final do seu artigo, Geffray descreve alguns dos fatores que contribuíram para dar credibilidade científica ao CEA, nomeadamente, o prestígio político e científico dos seus fundadores. Refere-se, neste caso, ao professor Aquino de Bragança e a Ruth First, que gozavam de certa influência nos meios políticos devido ao valor incontestável de suas produções científicas dentro de certos domínios; a reputação da reflexão "crítica" (aspas do autor) dos pesquisadores do Centro, bem como a adequação de uma linguagem às preocupações da elite no poder. ${ }^{65}$

\footnotetext{
${ }^{62}$ Ver Fernandes, "Dinâmicas". Para uma leitura das críticas deste autor, ver Geffray, "Fragments".

${ }^{63}$ Geffray, "Fragments", p. 73.

${ }^{64}$ Geffray, "Fragments", p. 76

${ }^{65}$ Geffray, "Fragments", p. 76.
} 
A crítica de Christian Geffray de que o CEA via o campesinato como uma massa homogênea é incorreta. A pesquisa coletiva do CEA, $O$ mineiro moçambicano, no último capítulo, intitulado "Trabalhadores ou camponeses?", faz uma análise exaustiva da base social do campesinato e uma discussão sobre as implicações políticas da organização dos camponeses em "aldeias comunais", devido às suas diferenciações de classe (os camponeses pobres, médios e ricos, como aqueles que migravam para as minas sul-africanas). De fato, os pesquisadores do Centro se distanciavam da "visão dualista" entre o "tradicional" e setor "moderno" (uma premissa que Christian Geffray parece assumir), argumentando que estes camponeses estavam profundamente penetrados pela acumulação capitalista. Esta discussão da "visão dualista" iria ser retomada pela pesquisadora do Centro, Bridget O'Laughlin no seu artigo "A questão agrária". ${ }^{66}$

Uma vez mais, a analítica de Gramsci pode ser útil aqui para esclarecer as características do trabalho intelectual do CEA no contexto totalitário da construção do socialismo em Moçambique. Como sabemos, na ótica deste autor havia uma diferença nítida entre "hegemonia política", um conceito leninista que implicava a ditadura do proletariado, e "hegemonia ideológica", que significava uma "liderança intelectual e moral" conseguida através do "consentimento ideológico das massas". ${ }^{67}$

Neste sentido, os intelectuais orgânicos do CEA seguiram a linha política da FRELIMO, não porque fossem coagidos, como aconteceria se o CEA fosse estritamente um órgão do Estado, não no sentido jurídico do termo, mas na ideia de que o seu trabalho de investigação se subordinava às diretrizes políticas do Estado, mas porque "consentiram

\footnotetext{
${ }^{66}$ Neste artigo, O'Laughlin reflete sobre uma das grandes preocupações do governo na altura, que era de aferir os motivos do fracasso da edificação das aldeias comunais em algumas regiões, da fraca participação camponesa, como também do persistente domínio da produção individual familiar em detrimento da política da produção coletiva e cooperativa. Para esta autora, as suas causas estavam relacionadas com a natureza da estrutura de classe rural deixada pela dominação do capitalismo colonial em Moçambique, mas também "com a falta de tomada de consciência do caráter urgente da cooperativização, como tarefa imediata da revolução, por alguns setores do próprio aparelho do Estado. Ver Bridget O'Laughlin, “A questão agrária em Moçambique", Estudos Mocambicanos, n.3 (1981), p. 27.

${ }^{67}$ Ver, Leonardo Salamini, "Gramsci and Marxist Sociology of Knowledge: An Analysis of Hegemony-Ideology-Knowledge”, The Sociological Quarterly, v. 15, n. 3 (1974), pp. 359-80.
} 
espontaneamente", uma vez que, parafraseando Gramsci, eles tinham "internalizado" o projeto hegemônico da FRELIMO,${ }^{68}$ ou pelo menos a interpretação que se dava a esse projeto frelimista, e o seu trabalho crítico servia, em última instância, como um fator legitimador do Estado. Cada um dos pesquisadores empregados pelo CEA via o seu trabalho acadêmico como politicamente engajado. Todos eles acreditavam que tinham um compromisso com o socialismo moçambicano e com a libertação da África do Sul e da Namíbia, e tudo o que faziam era moldado por essa crença.

\section{A guisa de conclusão: engajamento crítico, um oximoro?}

A seção anterior procurou estabelecer as interrelações do trabalho científico do CEA com o grupo político dominante, sem contudo reduzir essa conexão a uma adesão acrítica e dogmática aos desígnios do poder. Pelo contrário, o CEA, durante o período em análise, procura preservar um lugar onde pudesse exercer a crítica como uma reflexão sobre o próprio processo de produção de conhecimento. Os pesquisadores do CEA procuraram, ainda, distanciar-se de uma distinção rígida entre pesquisa social "aplicada" e uma reflexão sobre a própria produção de conhecimento. ${ }^{69}$ Foi, desse modo, produzida uma pesquisa social que envolvia, ao mesmo tempo, a teoria crítica e a pesquisa empírica. A Oficina de História e o Curso de Desenvolvimento são dois dos exemplos mais eloquentes dessa concepção de ciência social.

Neste artigo, procurou-se também abandonar a simples oposição entre autonomia da pesquisa social e a sua redução a uma função ideológica. Neste sentido, a exigência de uma pesquisa livre de valores não nos permitiria compreender todo um contexto social e político que foi determinante na definição das prioridades de pesquisa do CEA, bem como nas escolhas dos objetivos epistêmicos.

\footnotetext{
${ }^{68}$ Realçamos aqui o seu caráter dinâmico, em construção. Neste sentido, poderemos então falar de uma "hegemonia" da FRELIMO em perpétua construção e não algo já dado na sociedade. Argumentamos que é problemático afirmar que a FRELIMO foi de fato hegemônica em Moçambique.

${ }^{69}$ Ver por exemplo o discurso de Fernando Ganhão na abertura do primeiro ano letivo da UEM em 1976: "Problemas", p. 17.
} 
Esta aderência não significou, de forma alguma, uma distorção da realidade, ou tabula rasa da complexidade e heterogeneidade do social. Pelo contrário, a pesquisa do CEA esteve profundamente ligada ao trabalho empírico e ao respeito pelos resultados desse mesmo empreendimento. Como foi, por exemplo, o caso da pesquisa intitulada "Poder Popular e Desagregação nas Aldeias Comunais do Planalto de Mueda" (1985), em que os pesquisadores reportam a não aderência dos camponeses ao projeto político da organização coletiva da produção, reunindo argumentos para demonstrar o falhanço do projeto frelimista das aldeias comunais. Foi, pois, este "engajamento crítico" $" 70$ do CEA na produção de conhecimento científico-social que iria tornar o seu trabalho relevante e importante para um audiência vasta, dentro e fora da academia. Os pesquisadores do CEA lutaram para preservar um espaço onde pudessem desenvolver uma pesquisa crítica como a produção de um tipo de ciência social que poderia refletir sobre o próprio processo da produção de conhecimento.

$\mathrm{O}$ caso mais eloquente foi o artigo escrito por Aquino de Bragança e Jacques Depelchin intitulado "Da idealização da FRELIMO à compreensão da História de Moçambique. ${ }^{71} \mathrm{O}$ texto, apresentado num seminário organizado pelo CEA em fevereiro de 1986, refletia sobre as possibilidades de uma reescrita da história da FRELIMO e de Moçambique, a partir das contradições que o país vivia na altura. Seria assim, um convite à produção de uma pesquisa objetiva e iconoclasta sobre o percurso da FRELIMO, desde a luta de libertação nacional até a situação presente no controle do poder do Estado. Para Aquino de Bragança e Jacques Depelchin, era preciso formular novas perguntas, escrevendo deste modo a história da FRELIMO à luz das contradições que existem no seio da sociedade moçambicana contemporânea. A análise histórica deveria ir além da história "oficial", do "texto inalterável", aprofundando a crítica e analisando a "realidade tal como ela é", ${ }^{72}$ e não procurando dar respostas que apenas reforçassem a ideologia dominante e não fos-

\footnotetext{
${ }^{70}$ Allen Isaacman, "Legacies of Engagement: Scholarship Informed by Political Commitment", African Studies Review, v. 46, n.1 (2003), pp. 1- 41.

71 Aquino de Bragança e Jacques Depelchin, "Da idealização da FRELIMO a compreensão da História de Moçambique”, Estudos Moçambicanos, n.5/6 (1986), pp. 30-52.

72 Bragança e Depelchin, "Da idealização", p. 33.
} 
sem baseadas numa crítica objetiva dessas mesmas ideologias. Para estes autores, a história oficial tem a "tendência a ser uma história teleológica e autojustificativa". ${ }^{73}$

Podemos, portanto, encontrar quatro características principais deste "engajamento crítico" do CEA. Em primeiro lugar, a defesa de uma abordagem autorreflexiva e crítica na produção de conhecimento científico. Em segundo lugar, foi desenvolvido no Centro um trabalho de pesquisa, maioritariamente de caráter coletivo. Eram formadas, por exemplo, várias brigadas para uma determinada pesquisa, em que no final aparecia o "autor coletivo". Estas pesquisas procuravam enfatizar a "unidade entre a teoria e a prática", ${ }^{74}$ demonstrando que as soluções para o desenvolvimento socialista de Moçambique residiam numa ruptura com toda a historiografia colonial e na escolha de uma nova "teoria para a mudança social". ${ }^{75}$ Este binômio teoria-prática significava uma ligação estreita entre ensino teórico e a pesquisa empírica da realidade socioeconômica moçambicana. Foi, por outro lado, uma pesquisa coletiva preocupada com a libertação nacional dos países da África Austral sob domínio da África do Sul e do regime rodesiano. Daí, então, a grande divisa do CEA ser a de "analisar Moçambique no contexto da África Austral".

Em terceiro lugar, foi uma pesquisa com um caráter urgente e atual e que procurou examinar as estratégias de desenvolvimento do partido/Estado e a sua validade para a transformação social de Moçambique. Uma pesquisa científica com um propósito de, ao produzir esse conhecimento, ter uma função prática na sociedade. Os "Relatórios de Investigação" (alguns de difusão restrita), solicitados pelos vários órgãos do aparelho do Estado, são um exemplo eloquente da escolha, por parte do CEA, de uma ciência social "aplicada" e que pudesse refletir sobre os desafios da construção do socialismo em Moçambique.

E em último lugar, foi uma pesquisa que esteve preocupada com a formação de estudantes universitários e quadros do aparelho do Estado, através do Curso de Desenvolvimento, e com a criação de formas de

\footnotetext{
Bragança e Depelchin, "Da idealização", p. 33.

Ganhão, "Problemas", p. 9.

${ }_{5}$ Ganhão, "Problemas", p. 9.
} 
disseminação e debate dos resultados das suas pesquisas, através da revista Não Vamos Esquecer! e Estudos Moçambicanos, além da distribuição em vários órgãos dos Estados, como os ministérios, dos seus relatórios de pesquisa.

O grande desafio do CEA foi conquistar um espaço em que pudesse exercer a dúvida e olhar criticamente as causas sociais e políticas que seus membros apoiavam: a construção de uma alternativa socialista para Moçambique, mas também a libertação de toda África Austral do sistema capitalista sul-africano. E este "engajamento crítico" não era unicamente revelar as injustiças do imperialismo e, no caso moçambicano, a desestabilização promovida pelo regime do apartheid, mas formular questões cruciais de como este regime poderia ser aniquilado e como construir uma sociedade socialista em Moçambique. Portanto, não somente apoiar o modelo de desenvolvimento proposto pela FRELIMO, mas mostrar, quando foi o caso, os seus pontos fracos ou as suas incongruências.

Um outro ponto importante a salientar é o fato de o CEA ter tido autonomia financeira, fundamental para pôr a "máquina" da pesquisa e ensino a funcionar eficientemente, tanto em relação à universidade como de uma forma geral ao governo moçambicano. Estas instituições estatais colaboraram de outro modo, por exemplo, em questões logísticas; e no caso particular do governo, fundamentalmente na facilitação do trabalho de campo com as comunidades rurais, junto às estruturas administrativas locais, ou mesmo providenciando transporte para o contato com as comunidades rurais. Em termos financeiros, o CEA recebia apoio de instituições governamentais e não governamentais estrangeiras. Segundo Teresa Cruz e Silva,

O CEA tinha dois financiadores privilegiados e incondicionais, que estiveram sempre com o CEA: a SIDA ${ }^{76}$ e a SAREC,${ }^{77}$ que deu um financiamento institucional que foi até aos tempos do Sérgio Vieira. ${ }^{78} \mathrm{O}$ CEA

\footnotetext{
${ }^{76}$ SIDA - Swedish Internacional Development Cooperation Agency (Agência Sueca para o Desenvolvimento Internacional)

77 SAREC - Swedish Agency for Research Cooperation with Developing Countries (Agência Sueca para a Cooperação na Pesquisa com os Países em Desenvolvimento).

78 Sérgio Vieira, coronel na reserva e membro do "núcleo duro" da FRELIMO, tornou-se diretor do CEA, depois da morte de Aquino de Bragança em 1986.
} 
recebia o dinheiro e fazia o que queria com dinheiro e não prestava contas. Os suecos sempre foram amigos da FRELIMO. A ideia da SAREC era de permitir que houvesse uma instituição que desempenhasse um papel pivô na transformação da visão do que eram as Ciências Sociais e principalmente permitir que houvesse uma investigação e sem imposição de temas de pesquisa. ${ }^{79}$

Foram portanto estas características em conjunto (a presença de pesquisadores com sentido crítico, a autonomia financeira do Centro em relação ao governo e à universidade) que tornaram o trabalho de investigação do CEA, no pós-independência, único e que deveria ser visto não como um fim em si mesmo, como Geffray pensava, mas como um ponto de partida para a investigação científica ${ }^{80}$ Quer dizer, o CEA começou por apoiar e fazer das diretivas econômicas e sociais do partido FRELIMO as suas prioridades de pesquisa e, no final, acabava criticando aquelas mesmas políticas quando não refletiam os resultados das suas pesquisas empíricas. Não obstante sabermos que havia limites impostos pelo contexto social e político e que estruturavam a formação discursiva do CEA. ${ }^{81}$ Pois que, como assegurou Michel Foucault (1996),

\footnotetext{
${ }^{79}$ Entrevista com Teresa Cruz e Silva, agosto de 2007. p. 8.

${ }^{80}$ Harold Wolpe, sociólogo sul-africano e ativista anti-apartheid, defendia esta posição. Ele insistia que o trabalho intelectual e investigativo tinha que produzir conhecimento para a política, sem, no entanto desligar-se da investigação objetiva e científica do mundo. Ver, Peter Alexander, "Harold and History", Keynote delivered at the Harold Memorial Trust's Tenth Anniversary Colloquium, "Engaging Silences and Unresolved issues in the Political Economy of South Africa", n. 21-23 ( 2006), pp. 1-5.

${ }^{81}$ Por exemplo, o paradigma da economia política marxista que dominou o trabalho científico do CEA (fundamentalmente através do Curso de Desenvolvimento) acabou sendo mais "economicista" que "político", pois o CEA nunca se propôs a abordar questões relacionadas, por exemplo, a uma análise empírica na realidade moçambicana sobre "como aqueles que governam, governam?". Ou mesmo "como os dominantes e os dominados percebem essa mesma dominação? Poderíamos também incluir o tema do conflito armado contra a RENAMO. Como sabemos, para o CEA, como também para o partido no poder, a RENAMO era vista unicamente como uma força desestabilizadora criada fora de Moçambique. Durante este período da "transição socialista", a discussão nos círculos acadêmicos moçambicanos sobre a existência ou não de uma "guerra civil" em Moçambique, ou mesmo de o debate sobre os fatores internos do conflito - ligados, por exemplo, àquilo que Christian Geffray (1991), com a publicação do livro A causa das armas, em 1990, se referiu como o "descontentamento popular" advindo da ineficácia das políticas agrárias da FRELIMO e da marginalização das tradições locais e estruturas de autoridade - era, de fato improvável de acontecer naquele contexto histórico. Vide Christian Geffray, A causa das armas: antropologia da guerra contemporânea em Moçambique, Porto: Afrontamento, 1991.
} 
Gráfico 1 - Movimentação de pesquisadores (1976-1990)

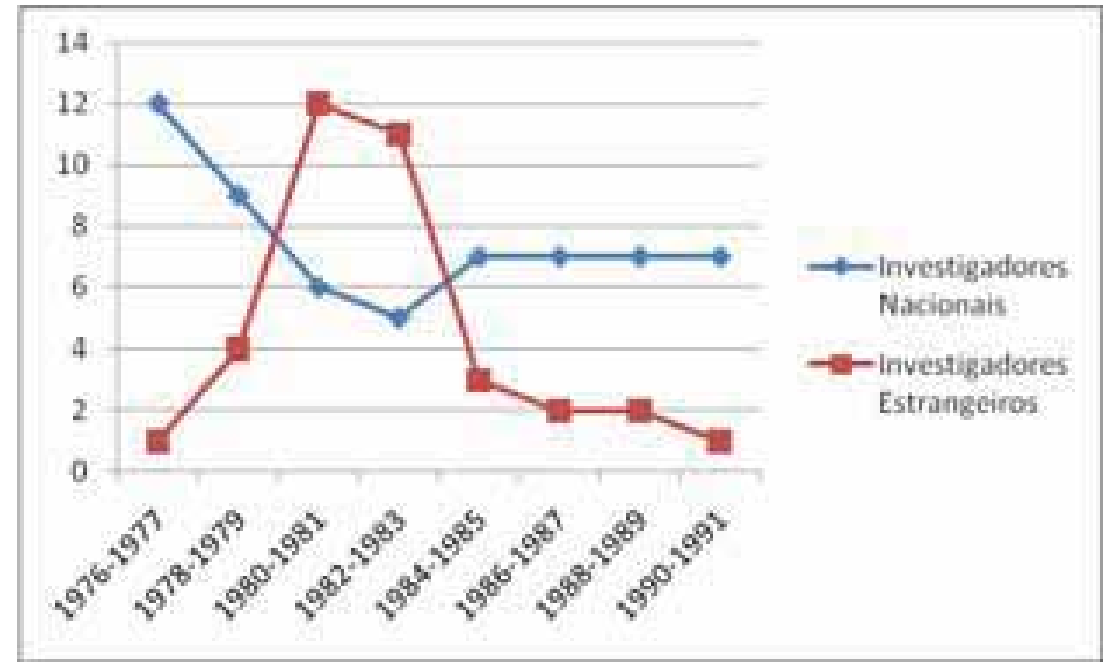

em toda sociedade a produção do discurso é ao mesmo tempo controlada, selecionada, organizada e redistribuída por certos números de procedimentos que têm por função conjurar seus poderes e perigos, dominar seu acontecimento aleatório, esquivar sua pesada e temível materialidade. ${ }^{82}$

Esta prática científica do CEA, de olhar de forma não ortodoxa as causas que apoiava, como de analisar a realidade social de forma crítica e independente, com o objetivo último da transformação social das condições de vida dos moçambicanos, começou gradualmente a declinar (ver Gráfico 1). O seu apogeu se deu com a assinatura dos Acordos de Nkomati, ${ }^{83}$ que, como vimos anteriormente, se traduziu na

82 Michel Foucault, A ordem do discurso, São Paulo: Loyola, 1996, p. 8.

83 Estes seriam tempos difíceis para o CEA, particularmente para o Núcleo da África Austral, como vimos, composto maioritariamente por pesquisadores sul-africanos e membros do CNA. Este grupo de pesquisa foi então proibido de produzir conhecimento sobre a situação política e econômica da África do Sul, como também de tecer qualquer manifestação pública sobre os Acordos de Nkomati. Como corolário desse "pacto de não agressão e boa vizinhança", as células clandestinas do CNA em Moçambique eram já consideradas proibidas e tinham que ser urgentemente desmanteladas. Por outro lado, não era permitida no meio universitário qualquer discussão sobre a validade desta viragem do governo. Os pesquisadores do CEA não podiam mais escrever sobre questões ligadas à África do Sul. 
saída de vários dos pesquisadores estrangeiros do CEA, particularmente daqueles ligados ao CNA. Outros fatores, no entremeio, iriam contribuir para esta crise do pensamento crítico: a morte de Ruth First em 1982, que daria um grande golpe na organização e liderança da pesquisa no Centro, como no Curso de Desenvolvimento que deixaria de exisitir, a crescente crise econômica e o agravamento da guerra civil no país.

A FRELIMO se tornava cada vez mais coerciva e dominante na sociedade, apertando ainda mais o espaço de discussão aberta, que o CEA tinha então conquistado. Não podemos argumentar, no entanto, que a pesquisa crítica tivesse desaparecido completamente, mas tinhase tornado mais difícil e requeria agora uma grande coragem para aqueles que ainda continuavam a fazê-la. Foi neste contexto que pesquisadores como Dan O'Meara, Sipho Dlamini, Robert Davies, Judith Head decidiram abandonar Moçambique, abdicando do seu trabalho de pesquisa e ensino no Centro.

Os Acordos de Nkomati podem então ser vistos como o ponto de partida de um longo processo de mudanças econômicas, políticas e intelectuais no país: (a) a abertura para uma economia de mercado, privilegiando o investimento privado, com a adesão de Moçambique ao FMI e BM; (b) a morte, em outubro de 1986, do presidente Samora Machel e de alguns dos seus "camaradas", dentre os quais o diretor do CEA, Aquino de Bragança, ${ }^{84}$ "num misterioso acidente de avião", ${ }^{85}$ (c) a sua sucessão, ordeira e consensual, ${ }^{86}$ pelo ministro dos negócios estrangeiros, Joaquim Chissano; (d) o fim da ideologia marxista-leninista; (e) a abertura ao

\footnotetext{
${ }^{84}$ Para o seu lugar foi nomeado, Sérgio Vieira, coronel (na reserva), ex-ministro da Segurança e membro do "núcleo duro" da FRELIMO. A partir daí um novo capítulo (que ultrapassa os limites históricos desta análise) da história intelectual deste Centro tomou lugar.

85 Merle Bowen, "Beyond Reform: Adjustment and Political Power in Contemporary Mozambique", The Journal of Modern African Studies, n. 30 (1992), pp. 255-79, 261.

86 Segundo Marina Ottaway, a morte de Samora serviu para enfatizar a continuidade da liderança da FRELIMO, em vez de significar uma nova viragem. Para esta autora, as reformas adotadas no pós-Nkomati foram feitas sem nenhuma modificação do sistema político ou mesmo de mudança de pessoal. Em suma, Moçambique passou de um "socialismo simbólico" para uma "reforma simbólica", uma vez que estava-se em presença de um "estado fraco" (soft state) em paralelo também com uma sociedade civil fraca, que não permitiram que as mudanças propostas tivessem o efeito desejado. Ver Marina Ottaway, "Mozambique: From Symbolic Socialism to Symbolic Reform", The Journal of Modern African Studies, n. 6 (1988), pp. 211-26.
} 
multipartidarismo e a liberdade de expressão com a nova Constituição da República de 1990; (f) e, por fim, em 1992 o cessar-fogo e os acordos gerais de paz entre o governo da FRELIMO e a RENAMO.

Neste artigo procuramos refletir sobre as condições sociais de produção de conhecimento científico num contexto particular da história de Moçambique, o período da "transição socialista", tendo como caso de estudo o Centro de Estudos Africanos da Universidade Eduardo Mondlane. Esta escolha obrigou-nos a "eclipsar" outros centros de pesquisa no país e que também desempenharam um papel importante na paisagem intelectual pós-independência, por exemplo, o departamento de História e o departamento de Antropologia/Arqueologia, ambos da UEM; o Arquivo Histórico de Moçambique, como também o Centro de Estudos de Técnicas Básicas para o Aproveitamento dos Recursos Naturais (TBARN). É preciso, no entanto, ressaltar que mais do que qualquer outro lugar de produção científica, o CEA, durante os "anos eufóricos" da "experiência socialista", acabou sendo a mais marcante e prolífica instituição de pesquisa, disseminação e publicação em ciências sociais.

A sua originalidade residiu na produção de um tipo de pesquisa científico-social que não somente levou em conta a sua função de produtora de conhecimento científico politicamente engajado na transformação socialista, mas também na reflexão e questionamento dos próprios processos de produção científica. Uma pesquisa que procurava refletir sobre si mesma. Foi, então, neste desejo ambivalente entre, por um lado, auxiliar a FRELIMO na sua visão de mundo socialista (que pressupunha uma abordagem pragmática, utilitária e não-epistemológica da realidade social) e, por outro lado, preservar um espaço de questionamento crítico e heterodoxo sobre a sociedade moçambicana e sobre o fazer ciência, que poderíamos então compreender as conexões entre produção científica e legitimação do Estado "freliminiano", como também a emergência de uma nova forma de se fazer pesquisa social no Moçambique pós-independência. Enfim, uma pesquisa politicamente engajada, urgente, atual, coletiva, crítica, utilitária e autorreflexiva.

Texto recebido em 4 de maio de 2012 e aprovado em 10 de dezembro de 2012 


\title{
Resumo
}

Usando o Centro de Estudos Africanos (CEA) da Universidade Eduardo Mondlane, como exemplo, este artigo analisa as condições sociais da produção de conhecimento e a legitimação do Estado no Moçambique pós-independente e durante a fase da "transição socialista". A tese do artigo é de que os processos de produção de conhecimento em um contexto da construção do estado nacional, geraram dinâmicas que desafiaram os pressupostos sobre os quais o CEA deveria fazer ciência. Por exemplo, na produção de um tipo de pesquisa que não só levou em consideração a sua função como pesquisa politicamente orientada, mas, na identificação e questionamento do próprio processo de produção científica. Estas inter-relações entre produção de conhecimento e legitimação do Estado, poderiam então, não só explicar as especificidades do CEA, mas também o surgimento de uma nova forma de questionamento científico-social no pós-independência.

Palavras chave: Intelectual orgânico - Ciências Sociais - engajamento crítico

\begin{abstract}
Using the Center for African Studies (CAS) at Eduardo Mondlane University as an example, this article analyzes the social conditions of knowledge production and legitimization of the post-independence Mozambican State, during the period of "socialist transition". The thesis of the article is that the processes of knowledge production in a context of national state-building generated dynamics that challenged the assumptions on which the CAS should have produced social science. For example, in producing a type of research program that not only took into account their function as policy-oriented research, but also in identifying and questioning the very process of scientific production. These inter-relationships between knowledge production and legitimization of the state, could then explain not only the specificities of the CAS, but also the emergence of a new form of socio-scientific questioning in post-independence Mozambique.
\end{abstract}

Keywords: Organic intellectual - social sciences - critical engagement. 